\title{
Lourival Gomes Machado
}

\section{OLIVEIROS S. FERREIRA}

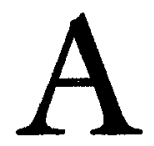

té onde a memória alcança, vejo Lourival Gomes Machado erguer-se numa histórica reuniāo da Esquerda Democrática e dizer, contrariando o voto de todos seus companheiros do dito Grupo do Centro, ou os trotskystas como nos chamavam para estigmatizar: "Por causa da posiçăo do companheiro Alípio Corrêa Neto, voto sim". E votou. Os demais companheiros do grupo, com direito a voto haviam se abstido porque Alípio colocara claramente o problema numa única intervençáo, precedendo o início da votação: se a posiçáo dos puros (não me recordo que palavra empregou para nos designar coletivamente) prevalecesse, ele se desligaria do partido. Não era uma ameaça vã: era ele, naquela altura dos acontecimentos, que pagava a sede.

O que estava em jogo era uma questáo de princípio: tendo sido cassados os mandatos dos parlamentares eleitos pelo Partido Comunista e redistribuídas as cadeiras, caberia à Esquerda Democrática mais um lugar na Câmara dos Vereadores de São Paulo. Que posição deveria adotar o partido? Os trotskystas - apodo que nos perseguiria por boa parte da existência - sustentavam a tese de que cada suplente deveria assumir e renunciar, assim forçando a realização de novas eleiçóes. Outros, os realistas que depois apoiaram Jânio, sustentavam, pelo contrário, que se deveria aproveitar a oportunidade para ter mais uma voz na Câmara. Lourival votou sim pela renúncia. E foi dormir tranqüilo. Dias depois, na Faculdade - ainda estávamos na praça da República, eu aluno de Ciências Sociais -, explicava que se tinha cansado da Esquerda Democrática, de lutas entre comunistas frustrados, tenentistas fora de época, socialistas democráticos.

Assim era ele: homem político por vocaçăo, alheio às cansativas noites de confabulaçôes para ganhar ou perder uma eleiçáo no diretório municipal. A ele deveria repugnar fazer a municipal; gostaria sem dúvida de fazer a federal.

Não tinha vocação de Juca Tigre, que tendo feito a federal e a estadual, ambas perdidas, fez a municipal e ocupou uma cidade no Rio Grande do Sul durante três meses. É esta vocaçáo pela federal que sem dúvida marcou sua passagem por São Paulo.

Lourival não passou apenas pela Faculdade de Filosofia, Ciências 
e Letras da Universidade de São Paulo, pela praça e depois pela Maria Antônia. Passou por Sáo Paulo e no pacato burgo de um milhăo e meio de habitantes deixou sua marca, hoje coberta pela poeira das geraçóes que se sucedem sem memória, mas que se tivesse ficado impressa, muitas coisas teriam sido diferentes - ou não teriam existido. Não falarei de sua passagem pelo Clima, que não o conheci nesta época, jovem demais para me ocupar com tertúlias desse tipo. Mas me lembro bem dele, chamado carinhosamente pelos amigos, especialmente Cândido, de o gordo não porque fosse gordo, mas porque era mais robusto que Cândido -, marcando sua presença no jornalismo, nas cátedras, nas artes, na Cidade, enfim. Como muitos da Faculdade de Filosofia, era do círculo do jornal $O$ Estado de $S$. Paulo. Foi repórter especial e cobriu a conferência da Organização dos Estados Americanos, em Petrópolis, da qual resultou o Tratado Interamericano de Assistência Recíproca. Nos arquivos do jornal ainda estaráo, sem dúvida, seus comentários à conferência e ao TIAR, nos quais espelhava sua crença em que os Estados latino-americanos, sendo maioria, poderiam impedir pelo voto à predominância, à hegemonia dir-se-ia hoje, dos Estados Unidos. Não era apenas uma ilusáo jurisdicista; era um pensamento que brotava dos tempos que se viviam, em que todos acreditavam, finda a guerra, que controvérsias não se resolveriam por açōes de pressão militar, mas pelo método democrático do voto. Eram comentários lúcidos, como lúcidas eram todas as notas sobre política internacional que escrevia para o Estado, abeberando-se no então farto noticiário e nas revistas internacionais que assinava, lia e de certa maneira resumia para o leitor do jornal. Nos arquivos encontrar-se-âo as notas, ou artigos assinados em que comentava a invasão de Costa Rica em 1955 (presidente, José Figueres) pelas forças de Somoza, a atitude viril do Uruguai colocando um, apenas um, aviăo à disposiçáo de uma Comissăo da OEA e assim forçando os Estados Unidos a tomar posiçáo contra Somoza, que em seguida retirou suas tropas do país invadido.

Năo foi no jornalismo diário, nem na condição de comentarista internacional, que Lourival firmou sua posiçăo na Cidade. Era um simpático burgo, que não pretendia disputar vantagens com o Rio de Janeiro, capital da República, sede dos ministérios, cidade onde pontificavam os intelectuais que eram a um tempo funcionários públicos e no Ministério da Educação haviam deitado fundas raízes que poderiam, se aprofundadas e outras fossem as circunstâncias, ter resultado num projeto cultural para o país: Simeáo Leal, dirigindo os serviços culturais, responsável sem dúvida pela publicação de revistas importantes, pela traduçáo de Romeu e Julieta, cuja primeira ediçăo foi logo recolhida porque Pennafort havia sido fiel na traduçáo da expressáo popular com 
que se identifica o himen. Rodrigo de Mello Franco, chefiando o Serviço do Patrimônio Histórico e Artístico, que tinha Luís Saia como seu zeloso representante em São Paulo. Os Irmáos Roberto não eram funcionários, mas disputavam com Niemeyer o primeiro lugar na arquitetura carioca. Náo sei se Drummond era de coterie, mas eram todos amigos por sobre as restriçóes do famoso artigo 13 do estatuto do $\mathrm{PCB}$, que proibia a seus membros ter relaçóes com trotskystas. Era a coterie, a patota amiga dos que amavam as artes plásticas na sua acepçáo mais ampla, as artes de uma maneira geral. Era, em certo sentido, a inteligência do Brasil, indo e vindo dos rincóes para o Rio e São Paulo (que

Lourival Gomes Machad

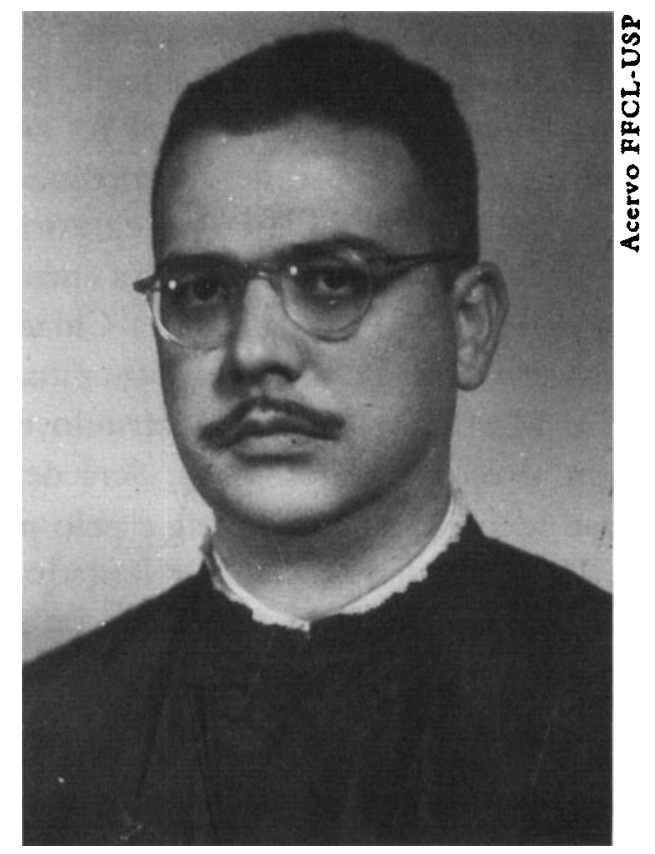

não disputava o primeiro lugar, mas não cedia o segundo), de Săo Paulo para o Rio e Belo Horizonte, que tinha seu peso.

Foi no campo das artes plásticas que Lourival Gomes Machado se tornou um membro da Cidade e nela deixou sua marca - e se o fez é também porque na Faculdade dera seu recado e também porque naqueles tempos a Cidade e a Faculdade eram uma e a mesma coisa, e ter posiçáo na praça ou na Maria Antônia era abrir caminho para ser recebido na Cidade. Não eram muitos os críticos de arte naquele tempo e Mário Pedrosa e Lourival concorriam com finuras florentinas pelo primeiro plano, um no Rio de Janeiro, outro na provinciana São Paulo. Disputavam a primazia de construir uma crítica de arte embasada não 
apenas em fundamentos estéticos, mas também sócio-culturais: era a época em que Mannheim perturbava as mentes com a Sociologia do Conhecimento e em que a Gestalt e a Psicologia Social - talvez o próprio Cassirer com suas formas simbólicas - davam um ar novo e diferente às críticas e à maneira de ver as artes plásticas.

Talvez tenha sido pelo fato de ser provinciana que São Paulo teve a audácia de pensar em fazer uma Bienal. Apoiada apenas no Museu de Arte Moderna, que era um centro cultural pequeno, mas imenso, em que sob a direçáo de Lourival - que dividia o tempo entre ele e a Maria Antônia - não apenas as artes plásticas marcavam lugar, em sadia e curiosa concorrência com o nascente Museu de Arte de São Paulo, mas também o cinema e muitas vezes a música nova que chagava em gravaçóes produzidas pouco depois da guerra. Sobre o Museu, São Paulo fez a primeira Bienal, da qual Lourival foi o diretor-artístico, o cérebro organizador, a alma capaz de compreender Francisco Matarazzo Sobrinho, o homem que sabia como contornar os entraves burocráticos alfandegários que poderiam impedir a entrada e depois a saída daquelas preciosas coleçốes que vinham dar à Cidade seu lugar no mundo universal das artes. Fazê-la foi seu orgulho, instalá-la no Trianon onde hoje se ergue o Masp, em prédio construído especialmente para ela, funcional sem arrojos arquitetônicos. Será de estranhar que da crítica de arte tivesse adentrado pela história e pelo patrimônio sobre o qual Rodrigo de Mello Franco zelava, e se lançado ao estudo do Aleijadinho e do barroco mineiro, e visto nas Gerais do século XVIII um projeto de cultura brasileiro?

Foi na arte que fez a sua federal, que o levou da Faculdade de Filosofia para a direçáo, creio, da Faculdade de Arquitetura, então na rua Maranhão, e de ambas para a Unesco, guardião das pirâmides, zelador das glórias de Veneza que a grande enchente ameaçava tornar coisa do passado vivido por outros há tempos. À Veneza não chegou para cumprir a missão. Outros a levaram a cabo por ele.

Se a memória não falha, vejo Lourival Gomes Machado, moço ainda, na praça, de avental como se vestiam os professores e assistentes, dando curso para quatro ou cinco alunos, moças a maioria, se não todas: Le socialisme de Durkheim. Depois, para classe pequena (eram pequenas as classes de Filosofia e Ciências Sociais naqueles tempos idos) na qual eu estava, tentando nos ensinar que a Política era uma ciência com objeto próprio, mas que deveria necessariamente empregar os métodos da Sociologia, pois sociologia especial era. Essa posição, hoje, é rejeitada e a Sociologia Política passou a ser Ciência Política, com objeto múltiplo e métodos idem. No ano seguinte, História das Idéias: Maquiavel e 
Rousseau. Quem assistiu às suas aulas não se esquecerá de seu vozeirão, das frases moduladas, da clareza do raciocínio que se compreendia ao primeiro contato, da finura com que analisava os textos, do rigor que reclamava de cada qual. Era notória na Faculdade a diferença entre o professor e o escritor: o quanto suas aulas ou conferências tinham de claro, seus textos eram rebuscados, barrocos, como que buscando esconder não se sabe o que.

$O$ professor era de um extremo rigor com ele mesmo. Naqueles tempos, a Faculdade costumava publicar Boletins, em que se imprimiam as teses ou escritos dos professores ou assistentes. Eram, como năo poderia deixar de ser, de tiragem média e circulação limitada mas marcavam a presença de todos no mundo acadêmico. A tese de doutoramento de Lourival versava exatamente sobre objeto método da Ciência Políti$\mathrm{ca}$, e datava de alguns anos atrás. Nunca quis que circulasse, fosse lida ou comentada. Dela esqueceu porque não representava mais o que pensava, ou porque fosse esforço de aprendiz. Lançou-se, então, à livredocência, aproveitando a vinda de Charles Morazé, que regeu a cadeira durante um ano. Seu amor pelo barroco e pelas Gerais levou-o a debulhar um texto quase inédito de Thomaz Antônio Gonzaga, o seu Tratado de Direito Natural - e me recordo do professor Morazé, ao argüí-lo, criticá-lo por haver escolhido um assunto que apenas ele, Lourival, podia conhecer. $O$ estudo de Gonzaga obrigava o conhecimento dos jusnaturalistas dos séculos XVII e XVIII, especialmente Grotius e seu tratado De jure belli ac pacis, que se encontrava na biblioteca da Faculdade de Direito - em latim. Lourival aprendeu latim para ler Grotius e todas as citaçóes desse pensador feitas na tese, para mal dos pecados meus e acréscimo às virtudes de Carla, que revisamos as provas tipográficas, foram feitas em latim. Era, seguramente, sua particular maneira de vingar-se do trabalho imenso que a elaboração conscienciosa de uma tese lhe dera. Depois, foi a vez de Rousseau, que sustentou para a cátedra, obra que ainda hoje abre caminhos para o conhecimento da obra do pensador genebrino, que leu inteira e utilizou toda inteira.

Assim era ele. A cadeira de Política inscrevia-se (como Sociologia e Antropologia) no Departamento de Ciências Sociais, em que olhos mais argutos já podiam ver nascer, embora cobertas ainda pelo capim, as sementes de futuras discórdias. Lourival, que apregoava, como disse, ser a Política uma Sociologia Especial, alimentou todo o tempo um sonho: fazer da Cadeira um departamento próprio em que fosse possível desenvolver as várias disciplinas que com tato vinha introduzindo no currículo obrigatório de Ciências Sociais, aumentando sem dúvida a carga de Política: História das Idéias, Formação do Estado Moderno (da qual se encarregou durante anos Paula Beiguelman, que o substituiu 
quando foi para a Unesco), Instituiçōes Políticas Brasileiras. Essa última era sua preferida, táo querida que no fundo desejava que todos seus assistentes pesquisassem o passado brasileiro para ver a gênese do presente que vivíamos. Quiseram os fados que nāo formasse o departamento - idéia que só venceu resistências de toda ordem bem mais tarde, quase agora - nem visse seus discípulos (exceto Paula) se dedicarem ao passado brasileiro.

Era um homem político. E fazia política na Faculdade, na grande coterie das Ciências Humanas sob a liderança de Fernando de Azevedo. Dr. Fernando, Lourival, Cruz Costa, primeiro Willems, depois Schaden, França e como năo poderia deixar de ser, o capitta Eurípedes, buscando ampliar sua influência na Faculdade. A concepçáo que Lourival tinha da Política náo era aceita sem mais aquela nesse círculo restrito de homens que lutavam por suas idéias como se fossem crianças suas. Recordo-me de quando expôs a Dr. Fernando sua definiçáo do fato político: "aproximação intersegmentar consciente", na qual se encontrava muito de Durkheim. Levada às últimas consequiências, dizia Dr. Fernando, o casamento será um fato político - com o que concordava Lourival, e contra o que protestava o nosso totem, admitindo, porém: "um casamento real pode ser tido como taln.

A ida para a Unesco tomou a todos nós da Política de surpresa e por que náo dizer, de uma sensaçáo de desamparo. Durante anos, ainda havia os que se lembravam dele. Depois, assim como aconteceu com a Cidade que dele perdeu a lembrança, são poucos os que se recordam de sua voz grave, seu corpanzil vestido do avental branco, a reserva para năo demonstrar afeto demais por ninguém, a aragem que fazia circular com sua cultura multifacetada (interdisciplinar, dir-se-ia hoje) no meio de assistentes, alunos e até mesmo de colegas. A Ciência Política, melhor dizendo a Política tout court, muito deve a ele na Faculdade. É apenas justo lembrar quem batalhou pela autonomia da Faculdade quando o Poder quis processar Cruz Costa e Schemberg; quem protestou contra a deposiçăo de Carlos Luz e Café Filho em 55, conseguindo da Congregação uma histórica moção em defesa da Constituiçáo e do Direito. Era um homem político, mas que detestava as sendas estreitas pelas quais trilhava a política brasileira, a geral e a particular. Por isso, antecipando-se à Unesco, deixou a Esquerda Democrática, sem alarde, simplesmente afirmando seu ponto de vista contra os que usavam do poder (!) para impor um ponto de vista.

Oliveires S. Ferreira é professor do Departamento de Ciéncia Política da Faculdade de Filosofia, Letras e Ciencias Humanas da USP e diretor de O Estodo de S. Puclo. 